A - preparing concepts

$\mathrm{B}$ - formulating methods

C - conducting research

$\mathrm{D}$ - processing results

E - interpretation and conclusions

$\mathrm{F}$ - editing the final version

\section{Virtual Reality as a Vestibular Rehabilitation tool for Athletes after Concussion: A literature review}

\author{
Lilian Felipe ${ }^{A, C-F * i D, ~ S i e r r a ~ H u n n i c u t t ~}{ }^{A-D, F}$ iD \\ Department of Speech and Hearing Sciences - College of Fine Arts and \\ Communication, Lamar University, United States
}

*Correspondence: Lilian Felipe; Lamar University, 4400 S M L King Jr Pkwy, Beaumont, TX 77705, US; e-mail: Ifelipe@lamar.edu

\begin{abstract}
Virtual Reality is cogitated as one of the most favorable and challenging technologies applied in health sciences. Its use has been integrated in vestibular rehabilitation for the management of balance conditions, founded on mechanisms related to neuronal plasticity of the central nervous system. Dizziness is one of the most common symptoms after a concussion in sports and can be an issue related to a long return to play. Virtual reality may be a beneficial method for rehabilitation for athletes with dizziness after concussion. However, no studies have critically reviewed the scientific evidence in this regard. The objective was to conduct a systematic review on the effectiveness of virtual reality as a rehabilitation strategy for athletes after a concussion. A systematic review of the electronic databases Cochrane Collection, Consumer Health Complete, Oxford Journals, PubMed, Science Direct, and SPORTDiscus was conducted to identify studies related to the effect of virtual reality after a concussion in athletes. The search timeframe ranged from January 1990 to December 2019. The search resulted in the identification of 3 randomized controlled trials (RCTs) and 7 non-RCT studies. None of the studies were specific associated with athletes with dizziness after a concussion. Specific studies are necessary to establish the application that may respond optimally to the treatment of concussions associated with balance problems.
\end{abstract}

Keywords: balance, athletes, virtual reality, vestibular rehabilitation, concussion

\section{Introduction}

Between 1.1-1.9 million sport-related concussions occur in the United States of America every year [1]. Concussions can cause issues in behavioral, emotional, and memory aspects, and also balance issues $[2,3]$. A guided clinical evaluation is performed before the decision to return-to-play [4].

Concerning to balance disorders, the Vestibular Rehabilitation is a scientific method to improve balance. The specialized exercises exposure the patient to different sensory inputs, facilitation vestibular recovery [5].

Virtual Reality (VR) is a term used to describe a computer technology designed to simulate an environment. VR has been used for instructive and amusement reasons. Currently, a huge number of studies using this technology in healthcare conducts physicians with future benefits and patient improvement outcomes [6-8].

In the balance management, it is new device used in combination with vestibular rehabilitation and have presenting potential efficacy [8]. Recent studies have been 
conducted to evaluate the process and benefits in using virtual reality within rehabilitation settings [5,9-11].

The purpose of this systematic review is to verify scientific evidence of Virtual Reality associated with Vestibular Rehabilitation in athletes, after a concussion.

\section{Material and methods}

This systematic review was guided by Preferred Reporting Items for Systematic Review and Meta-Analysis Protocols (PRISMA-P) [12].

The search timeframe ranged from January 1990 to December 2019. Articles written before 1990 were not considered due to the insufficiency of technology. The databases utilized were Cochrane Collection, Consumer Health Complete, Oxford Journals, PubMed, Science Direct, and SPORTDiscus. The keywords were "Virtual Reality", "Concussion", "Vestibular" and "Athletes" with the Boolean operator "AND" between terms.

The titles of all the studies from each database were enumerated on a Word Table document to identify doubled publications.

The inclusion criteria were (1) athletes diagnosed with concussion; (2) original data applying vestibular rehabilitation in combination with virtual reality; (3) reporting at least one outcome measure related to the efficacy of the treatment; (4) written in English, Portuguese or Spanish. Studies were excluded if: (1) were case reports; (2) does not include athletes with concussion; (3) analyzed the effects of vestibular rehabilitation without virtual reality; (4) applied virtual reality in combination with other rehabilitative therapies nonrelated to vestibular rehabilitation.

After a screening process realized by the authors to exclude duplicates, the titles and abstracts of the remaining studies were individually selected according the inclusion and exclusion criteria.

The data extraction procedure was not blind once all the manuscript information related to journal, institution, authors, study design, intervention, outcomes were evident.

Previous to the process of data extraction, it was conducted a pilot in 10 studies selected arbitrarily.

\section{Results}

The course of the systematic review is presented in Figure 1. The electronic database search yielded 31 records after duplicates were removed.

The examination of titles and abstracts resulted in the retrieval of 142 full-text records. Following full-text review, 10 studies were included in qualitative analysis (Table 1).

All the studies conducted evaluated both genders. The sample size ranged from 42 to 50 subjects in period from 2 (two) weeks to 4 (four) months. The interventions focused primarily on improving balance. The focus on outcomes were of the effectiveness of virtual reality as a tool within rehabilitation.

Exercise training interventions included participants walking on moving platform to evaluate posture, sway, and gait speed. Individuals were given multiple tasks to complete and multitasked during sessions to evaluate dual-tasking skills. Each study assessed different outcome measurements. The application of vestibular rehabilitation in concussions were found in one article, but it does not include the virtual reality technology.

No data was found regarding athletes with concussions correlated with vestibular rehabilitation and virtual reality.

\section{Discussion}

Vestibular rehabilitation is a comprehensive, individualized exercise approach to assessing and treating symptoms due to disorders of the vestibular and balance systems. The goal of therapy is to reduce symptoms, improve postural control, gain and gaze instabilities to return to activities of daily living [10-13,18,20].

The purposes of Vestibular Rehabilitation are 1) enhancing gaze stability, 2) enhancing postural stability, 3) improving vertigo, and 4) improving daily living activities [10].

The knowledge of the patient's diagnosis is a critical foundation for planning comprehensive treatment programs with the goal to reduce impairment and symptoms and expedite the return to daily activities, sports, or work [9-13].

Literature corroborate that subjects with head injuries experience substantial disability due to vestibular symptoms. Their conditions often include cognitive and central vestibular involvement along with a peripheral component.

Traditional vestibular rehabilitation is commonly applied for athletes with concussions to reduce returnto-play time $[17,20]$, but no studies applied this technique in combination with virtual reality in this population. There is limited research regarding virtual reality in vestibular rehabilitation [19,20-23]. Studies presented that rugby and snowboarding athletes had their sensorimotor skills, and dynamic posture improved using vestibular exercises combined with virtual reality technology $[13,14]$, but any study evaluate this tool to recover balance after a concussion. Trials concluded that 


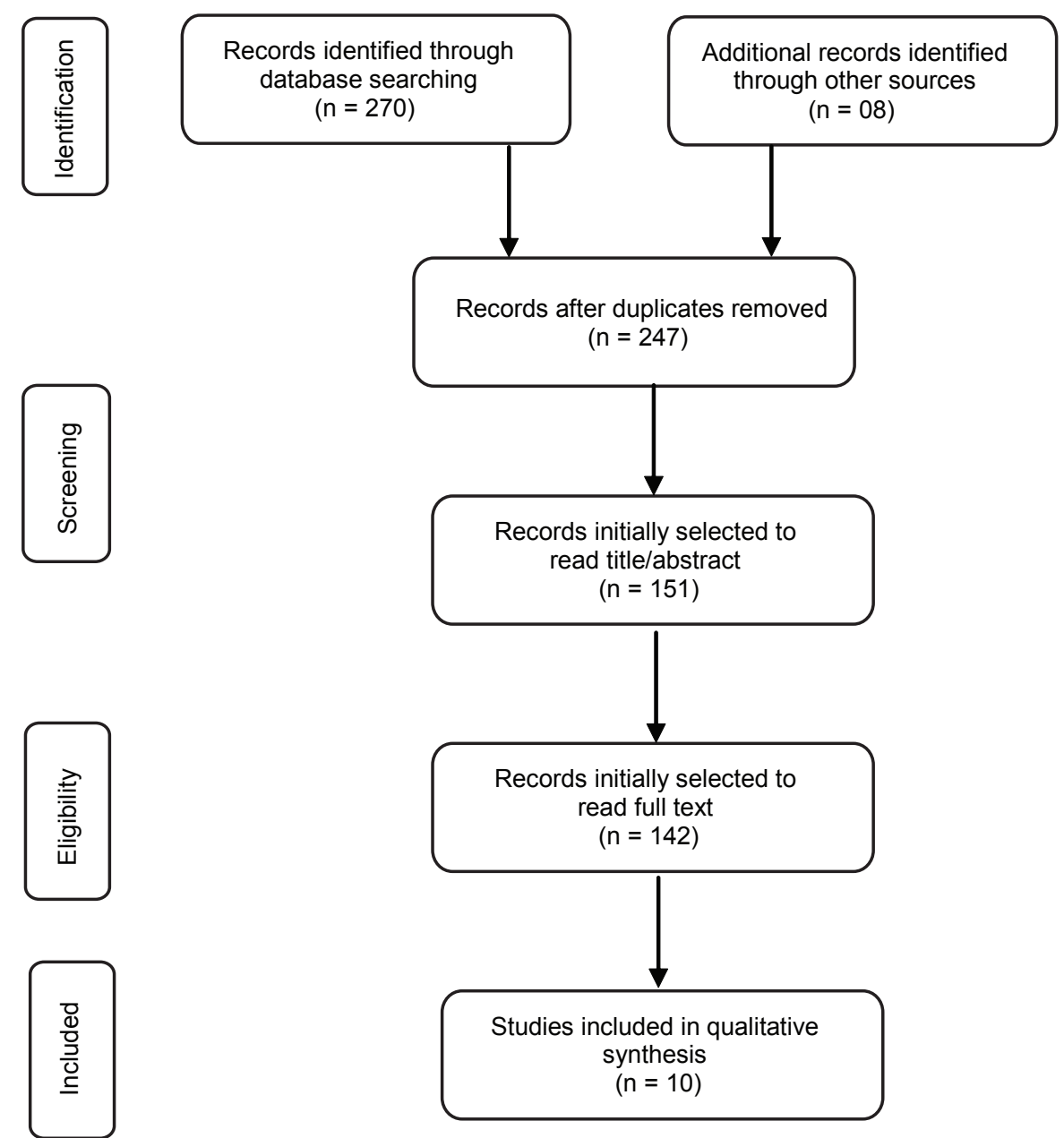

Fig. 1. Results of the Systematic Review Process

Tab. 1. Characteristics of the studies included in the systematic review

\begin{tabular}{|c|c|c|c|c|c|}
\hline $\begin{array}{l}\text { First author, } \\
\text { year }\end{array}$ & Study design & Participants & $\begin{array}{l}\text { Intervention and } \\
\text { Comparison group }\end{array}$ & $\begin{array}{l}\text { Outcomes } \\
\text { of interest }\end{array}$ & Results \\
\hline $\begin{array}{l}\text { Miles, } \\
2012[21]\end{array}$ & $\begin{array}{l}\text { Systematic } \\
\text { review }\end{array}$ & $\begin{array}{l}\text { Review aimed to look } \\
\text { at athletes who have } \\
\text { used virtual reality } \\
\text { as a tool for skill } \\
\text { improvement. }\end{array}$ & $\begin{array}{l}\text { Athletes were } \\
\text { reviewed, no } \\
\text { experimental } \\
\text { group. }\end{array}$ & $\begin{array}{l}\text { Virtual } \\
\text { Environment for } \\
\text { sensorimotor skill } \\
\text { improvement }\end{array}$ & $\begin{array}{l}\text { A virtual environment has } \\
\text { the potential to help players } \\
\text { with real life skills in } \\
\text { a sports game. }\end{array}$ \\
\hline $\begin{array}{l}\text { Wada, } \\
2016 \text { [14] }\end{array}$ & Case study & $\begin{array}{l}\text { Forty-two healthy } \\
\text { young subjects } \\
\text { participated in the } \\
\text { study. }\end{array}$ & $\begin{array}{l}\text { Participants went } \\
\text { through testing } \\
\text { as a collective } \\
\text { group. }\end{array}$ & $\begin{array}{l}\text { Time lags between } \\
\text { vision, body } \\
\text { rotation and head } \\
\text { stability. }\end{array}$ & $\begin{array}{l}\text { The virtual reality } \\
\text { environment improved } \\
\text { dynamic posture control } \\
\text { and improved their motor } \\
\text { performance in real world } \\
\text { setting. }\end{array}$ \\
\hline $\begin{array}{l}\text { Broglio, } \\
2015 \text { [20] }\end{array}$ & $\begin{array}{l}\text { Systematic } \\
\text { review }\end{array}$ & $\begin{array}{l}\text { Review focuses } \\
\text { on Athletes who } \\
\text { have experienced } \\
\text { brain trauma and } \\
\text { concussions. }\end{array}$ & $\begin{array}{l}\text { Athletes with } \\
\text { concussions }\end{array}$ & $\begin{array}{l}\text { Finding the } \\
\text { most effective } \\
\text { rehabilitation } \\
\text { method for athletes } \\
\text { with concussions. }\end{array}$ & $\begin{array}{l}\text { Emerging evidence } \\
\text { suggests that exercise } \\
\text { and cognitive activity in } \\
\text { a controlled environment } \\
\text { and manner may benefit } \\
\text { recovery for sport-related } \\
\text { concussion. }\end{array}$ \\
\hline
\end{tabular}




\begin{tabular}{|c|c|c|c|c|c|}
\hline $\begin{array}{l}\text { First author, } \\
\text { year }\end{array}$ & Study design & Participants & $\begin{array}{l}\text { Intervention and } \\
\text { Comparison group }\end{array}$ & $\begin{array}{l}\text { Outcomes } \\
\text { of interest }\end{array}$ & Results \\
\hline $\begin{array}{l}\text { Parker, } \\
2008 \text { [17] }\end{array}$ & Case study & $\begin{array}{l}\text { Athletes and } \\
\text { non-athletes who } \\
\text { have experienced } \\
\text { a concussion. }\end{array}$ & $\begin{array}{l}\text { Athletes and non- } \\
\text { athletes }\end{array}$ & Balance control & $\begin{array}{l}\text { Athletes walked slower } \\
\text { and swayed more than the } \\
\text { non-athletes. Even non- } \\
\text { concussed, athletes showed } \\
\text { imbalance. }\end{array}$ \\
\hline
\end{tabular}

The participants in group 1 , using CAREN, improved in gait speed and weight shift. By the end of the therapy (Week 6), speeds ranged from 0.60 to $1.50 \mathrm{~m} / \mathrm{s}$. Self-

Group 1

Military Service members. Participants were between the ages of 20 and 42.

Sessoms, Randomized 2015 [16] control study
Patients presented with vestibular disorders related to a mild Traumatic Brain Injury (mTBI) occurring within the past year. participated in

therapy sessions

with Computer-

Assisted

Rehabilitation

Environment

(CAREN), group

2 participated

in vestibular

rehabilitation

using traditional

methods and

techniques.
Gait speed and weight shift selected walking speeds for the control group.

There was not a statistically significant main effect for group type. However, there was a significant effect for time point, with walking speeds increasing over time in both groups. Group 1 walked significantly slower compared to the Control group at Visit 1 Visit 2 and Visit 3, but not for Visit 4 Visit 5, or Visit 6.

Group 2 walking speeds were significantly slower than the Control group at Visit 1 and Visit 2.

\begin{tabular}{|c|c|c|c|c|c|}
\hline $\begin{array}{l}\text { Linder, } \\
2019 \text { [22] }\end{array}$ & Case Study & $\begin{array}{l}50 \text { healthy, young } \\
\text { adults. Ranged from } \\
18-24 \text { years old. } \\
\text { Participants with no } \\
\text { active neurologic } \\
\text { or musculoskeletal } \\
\text { condition resulting } \\
\text { in impaired postural } \\
\text { stability. }\end{array}$ & $\begin{array}{l}\text { Adults were } \\
\text { together in one } \\
\text { group for all tests. }\end{array}$ & $\begin{array}{l}\text { Dual-tasking and } \\
\text { motor performance. } \\
\text { Postural stability } \\
\text { was quantified } \\
\text { using data gathered } \\
\text { from accelerometer } \\
\text { and gyroscope. } \\
\text { Cognitive task } \\
\text { difficulty was } \\
\text { manipulated } \\
\text { by presenting } \\
\text { stimuli at } 30,60 \\
\text { or } 90 \text { per minute. } \\
\text { Performance of } \\
\text { cognitive and } \\
\text { balance tasks was } \\
\text { compared between } \\
\text { single- and dual- } \\
\text { task trials. }\end{array}$ & $\begin{array}{l}\text { Difference in postural con- } \\
\text { trol was found in the stance } \\
\text { of tandem with eyes closed. } \\
\text { Improvement in postural } \\
\text { stability was found within } \\
\text { dual-task situations. }\end{array}$ \\
\hline $\begin{array}{l}\text { Maggio, } \\
2019 \text { [18] }\end{array}$ & $\begin{array}{l}\text { Systematic } \\
\text { Review }\end{array}$ & $\begin{array}{l}\text { Traumatic Brain } \\
\text { Injury }(\mathrm{TBI})^{2} \text { patients } \\
\text { who are experiencing } \\
\text { vestibular } \\
\text { dysfunction. }\end{array}$ & $\begin{array}{l}\text { Patients with } \\
\mathrm{TBI}^{2} \text { who have } \\
\text { vertigo. }\end{array}$ & $\begin{array}{l}\text { Rehabilitation tool } \\
\text { and assessment tool } \\
\text { validity of virtual } \\
\text { reality for } \mathrm{TBI}^{2} \\
\text { patients. }\end{array}$ & $\begin{array}{l}\text { Virtual Reality has } \\
\text { the potential be an } \\
\text { effective assessment and } \\
\text { rehabilitation tool to treat } \\
\text { TBI patient's cognitive and } \\
\text { behavioral problems. }\end{array}$ \\
\hline
\end{tabular}




\begin{tabular}{|c|c|c|c|c|c|}
\hline $\begin{array}{l}\text { First author, } \\
\text { year }\end{array}$ & Study design & Participants & $\begin{array}{l}\text { Intervention and } \\
\text { Comparison group }\end{array}$ & $\begin{array}{l}\text { Outcomes } \\
\text { of interest }\end{array}$ & Results \\
\hline $\begin{array}{l}\text { Pietrzak, } \\
2014 \text { [19] }\end{array}$ & $\begin{array}{l}\text { Systematic } \\
\text { Review }\end{array}$ & $\begin{array}{l}\text { This review focuses } \\
\text { on } \mathrm{TBI}^{2} \text { adult } \\
\text { patients. }\end{array}$ & $\begin{array}{l}\text { Adults who have } \\
\text { suffered } \mathrm{TBI}^{2} \text {. }\end{array}$ & $\begin{array}{l}\mathrm{TBI}^{2} \text { patients in } \\
\text { virtual reality } \\
\text { rehabilitation. }\end{array}$ & $\begin{array}{l}\text { Virtual reality in } \\
\text { rehabilitation of traumatic } \\
\text { brain injury can improve } \\
\text { motor and cognitive } \\
\text { functionality. However, } \\
\text { research on the topic is } \\
\text { very limited. }\end{array}$ \\
\hline $\begin{array}{l}\text { Wright, } \\
2016 \text { [23] }\end{array}$ & $\begin{array}{l}\text { Randomized } \\
\text { control study }\end{array}$ & $\begin{array}{l}\mathrm{mTBI}^{1} \text { patients who } \\
\text { experience vestibular } \\
\text { dysfunction. }\end{array}$ & $\begin{array}{l}\text { Healthy adults } \\
\text { and adults with } \\
\text { mTBI }^{1} \text {. }\end{array}$ & $\begin{array}{l}\text { Sensory } \\
\text { Organization Test } \\
\text { (SOT) using Virtual } \\
\text { Environment TBI } \\
\text { Screen (VETS). }\end{array}$ & $\begin{array}{l}\text { The VETS is valid for } \\
\text { detecting imbalance issues } \\
\text { within } \mathrm{mTBI}^{1} \text { patients. } \\
\text { Patients with } \mathrm{mTBI}^{1} \text { did } \\
\text { worse than the healthy } \\
\text { adults. }\end{array}$ \\
\hline $\begin{array}{l}\text { Meldrum, } \\
2015 \text { [15] }\end{array}$ & $\begin{array}{l}\text { Randomized } \\
\text { control study }\end{array}$ & Vertigo patients & $\begin{array}{l}\text { Group } 1 \text { in } \\
\text { conventional } \\
\text { treatment and } \\
\text { group } 2 \text { in } \\
\text { virtual reality } \\
\text { based vestibular } \\
\text { rehabilitation. }\end{array}$ & $\begin{array}{l}\text { Gait speed, } \\
\text { Posturography and } \\
\text { Dynamic Visual } \\
\text { Acuity. }\end{array}$ & $\begin{array}{l}\text { Results suggest that } \\
\text { Nintendo Wii }{ }^{\circledR} \text { Fit Plus } \\
\text { (NWFP) in vestibular } \\
\text { rehabilitation could assist } \\
\text { therapists in treating } \\
\text { patients who unilateral } \\
\text { peripheral vestibular loss. }\end{array}$ \\
\hline
\end{tabular}

1. mild Traumatic Brain Injury (mTBI): is the most common type of traumatic brain injury $[2,9]$.

2. Traumatic Brain Injury (TBI): it is defined a disruption in the normal function of the brain that can be caused by a bump, blow, or jolt to the head, or penetrating head injury. A TBI can range in severity, including transient symptoms and fatal hemorrhages $[1,16,18]$.

virtual reality within vestibular rehabilitation improve motor skills $[13,14]$, potentially increase task achievement-rates [15-18], and memory [16-19].

Researches are necessary to determine the application of virtual reality associated with vestibular rehabilitation in treatment of concussions associated with balance problems. Due to the growth and development of virtual reality technology for rehabilitation, future randomized studies with greater samples are crucial. Combining vestibular therapeutic to modern techniques can established physical therapy program to benefit individuals returning to play.

The combination of vestibular rehabilitation and virtual reality after a concussion in sports could enhance the balance ability of the athlete and reduce the return to play period. These two aspects will improve quality of life and safe financial expenses.

\section{Future considerations}

The Virtual Reality furnish an interface with a computer-generated environment and a level of stimulation that offer the user to have a real-time interaction. To implement this technology linked up to Vestibular Rehabilitation for athlete's post-concussion, it is necessary to have interaction and immersion for the training balance. The interaction is reached within a diversity of multisensory stimuli, allowing the subject to interact with the virtual domain. The immersion represents the level of impression to be enclosed in the virtual world. Both interaction and immersion characterize the feedback for the sensory structures (visual, vestibular and proprioception) and the central nervous system, modifying postural control and equilibrium.

For a vestibular rehabilitation program associated with virtual reality, it is crucial to have: (1) manipulation of feedback; creating conflicts among the systems whereas additionally allow the training of these systems and (2) stimulating the static and dynamic postural control.

The idea is evaluating the athlete's performance and provide quantitative scoring. The measures consist in head's motion, pressure center, sway in different directions and muscular activity register.

We expect that this technology will assist coaches to develop better players and improve decision-making return to play. It will also be crucial in aspects of an athlete's performance which require changing, for example, their biomechanics or technique. The exposure of athletes in a virtual environment might amplified the amount of play repetitions without the risk of another injury. Moreover, it will support athletes to have a more enjoyable recovery, increase their concentration and provide faster and better results. 


\section{Conclusion}

No data was found applying vestibular rehabilitation and virtual reality in athletes with concussions. Current evidence for optimal prescription and efficacy of vestibular rehabilitation in subjects with vestibular disorder and concussion is limited.

Further high-level studies evaluating the effects of vestibular rehabilitation associated to virtual reality in athletes with concussion and balance dysfunction are indispensable to demonstrate the efficacy comparing results with and without this technology.

The conception of a virtual reality to stimulate equilibrium and be applied as a rehabilitation tool associated with vestibular exercises may allow athletes to a faster return to play after a concussion, better recover with enhance of balance skills and improvement in field.

\section{Funding}

This work was supported by McNair Scholars Program.

\section{Conflicts of interest}

The authors declare no conflict of interest.

\section{References}

1. Langlois JA, Rutland-Brown W, Wald MM. The epidemiology and impact of traumatic brain injury: A brief overview. J Head Trauma Rehabil. 2006 SepOct; 21(5): 375-8.

2. Jotwani V, Harmon KG. Post-concussion syndrome in athletes. Curr Sports Med Rep. 2010 Jan-Feb; 9(1): 21-6.

3. Covassin T, Moran R, Wilhelm K. Concussion symptoms and neurocognitive performance of high school and college athletes who incur multiple concussions. Am J Sports Med. 2013 Dec; 41(12): 2885-9.

4. Guskiewicz KM. Postural stability assessment following concussion: One piece of the puzzle. Clin J Sport Med. 2001 Jul; 11(3): 182-9.

5. Lange B, Flynn S, Proffitt R, Chang CY, Rizzo AS. Development of an interactive game-based rehabilitation tool for dynamic balance training. Top Stroke Rehabil. 2010 Sep-Oct; 17(5): 345-52.

6. Quaglini S, Alloni A, Cattani B, Panzarasa S, Pistarini C. Computerized Cognitive Rehabilitation: Comparing Different Human-Computer Interactions. Stud Health Technol Inform. 2017 Oct 2; 245(1): 1374.

7. Kim WS, Lee K, Kim S, Cho S, Paik NJ. Transcranial direct current stimulation for the treatment of motor impairment following traumatic brain injury. J Neuroeng Rehabil. 2019 Jan 25; 16(1): 14.
8. Kim JH. Effects of a virtual reality video game exercise program on upper extremity function and daily living activities in stroke patients. J Phys Ther Sci. 2018 Dec; 30(12): 1408-11.

9. Gioia GA, Glang AE, Hooper SR, Brown BE. Building Statewide Infrastructure for the Academic Support of Students With Mild Traumatic Brain Injury. J Head Trauma Rehabil. 2016 Nov/Dec; 31(6): 397-406.

10. Alahmari KA, Sparto PJ, Marchetti GF, Redfern MS, Furman JM, Whitney, S.L. Comparison of virtual reality-based therapy with customized vestibular physical therapy for the treatment of vestibular disorders. IEEE Trans on Neural Syst Rehabil Eng. 2014 Mar; 22(2): 389-99.

11. Prasertsakul T, Kaimuk P, Chinjenpradit W, Limroongreungrat W, Charoensuk W. The effect of virtual reality-based balance training on motor learning and postural control in healthy adults: A randomized preliminary study. Biomed Eng Online. 2018 Sep 18; 17(1): 124.

12. Moher D, Shamseer L, Clarke M. Preferred reporting items for systematic review and meta-analysis protocols (PRISMA-P) 2015 statement. Syst Rev. 2015 Jan $1 ; 4: 1$.

13. Faure C, Limballe A, Bideau B, Kulpa R. Virtual reality to assess and train team ball sports performance: A scoping review. J Sports Sci. 2020 Jan; 38(2): 192-205.

14. Wada Y, et al. Effects of repeated snowboard exercise in virtual reality with time lags of visual scene behind body rotation on head stability and subjective slalom run performance in healthy young subjects. Acta OtoLaryngol. 2016 Nov; 136(11): 1121-24.

15. Meldrum D, et al. Effectiveness of conventional versus virtual reality-based balance exercises in vestibular rehabilitation for unilateral peripheral vestibular loss: Results of a randomized controlled trial. Arch Phys Med Rehabil. 2015 Jul; 96(7): 1319-28.

16. Sessoms PH, Gottshall KR, Collins JD, Markham AE, Service KA, BS Reini. Improvements in gait speed and weight shift of persons with traumatic brain injury and vestibular dysfunction using a virtual reality computer-assisted rehabilitation environment. Mil Med. 2015 Mar; 180(3 Suppl): 143-9.

17. Parker TM, Osternig LR, Donkelaar PV, Chou L. Balance control during gait in athletes and non-athletes following concussion. Med Eng Phys. 2008 Oct; 30(8): 959-67.

18. Maggio MG, et al. Cognitive rehabilitation in patients with traumatic brain injury: A narrative review on the emerging use of virtual reality. J Clin Neurosci. 2019 Mar; 61: 1-4.

19. Pietrzak E, Pullman S, Mcguire A. Using Virtual Reality and Videogames for Traumatic Brain Injury 
Rehabilitation: A Structured Literature Review. Games Health J. 2014 Aug; 3(4): 202-14.

20. Broglio SP, Collins MW, Williams RMA, Kontos AP. Current and Emerging Rehabilitation for Concussion: a review. Clin Sports Med. 2015 Apr; 34(2): 213-31.

21. Miles HC, Pop SR, Watt SJ, Lawrence GP, Hohn NW. A review of virtual environments for training in ball sports. Comput Graph. 2012 Oct; 36(6): 714-26.
22. Linder SM, Koop MM, Ozinga S, Goldfard Z, Alberts JL. A Mobile Device Dual-Task Paradigm for the Assessment of mTBI. Mil Med. 2019 Mar 1; 184(Suppl 1): 174-80.

23. Wright WG, McDevitt J, Tierney R, Haran FJ, AppiahKubi KO, Dumont A. Assessing subacute mild traumatic brain injury with a portable virtual reality balance device. Disabil Rehabil. 2017 Jul; 39(15): 1564-72. 